\title{
The sustainable clothing market: an evaluation of potential strategies for UK retailers
}

\author{
Helen Goworek \\ Business School, Nottingham Trent University, Nottingham, UK \\ Tom Fisher \\ School of Art and Design, Nottingham Trent University, Nottingham, UK \\ Tim Cooper \\ College of Art, Design and the Built Environment, Nottingham Trent University, \\ Nottingham, UK \\ Sophie Woodward \\ Department of Sociology, University of Manchester, Manchester, UK, and \\ Alex Hiller \\ Business School, Nottingham Trent University, Nottingham, UK
}

\begin{abstract}
Purpose - This paper aims to investigate consumers' perspectives on sustainable clothing consumption and to examine ways in which this information could influence retailers' policies.

Design/methodology/approach - Qualitative research was conducted using focus groups, home tasks and workshops with 99 participants. The sample represented different groups of consumers in relation to their sustainability behaviour.

Findings - Focus group participants had a limited awareness of the sustainability impacts of clothing. Where participants displayed pro-environmental behaviour, this was not necessarily intentional, but was largely a response to other influences. The respondents' maintenance and disposal of clothes were found to be influenced mainly by existing habits and routines, which usually take precedence over awareness of sustainable practice. The research indicated that consumers could be persuaded to change their behaviour in relation to sustainability by being encouraged and enabled to reflect more on their behaviour.

Research limitations/implications - This study uses qualitative research and is limited to UK consumers. Future research in this field could incorporate quantitative methods or in-depth interviews. Academics could conduct further research and generate theories which apply to the sustainable consumption of clothing.

Social implications - The findings have implications for retailers, academics and society. Retailers can develop and implement more sustainable policies and practices in relation to clothing production and consumption. There are wider implications for society and the environment in that retailers' practices can impact greatly on the sustainability of the planet's resources.

Originality/value - This paper's originality lies in its assessment of the implications for retailers of consumers' views on the sustainable consumption of clothing.

Keywords Sustainability, Sustainable clothing, Clothing retailers, Consumer behaviour, Ethical consumerism, Fair trade, Choice editing, Focus groups, Qualitative research, Retail trade, Corporate social responsibility

Paper type Research paper
\end{abstract}

The sustainable clothing market

935

Received October 2011

Revised May 2012

Accepted May 2012

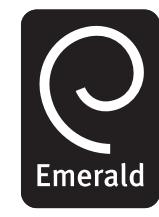

International Journal of Retail
\& Distribution Management
Vol. 40 No. 12,2012
pp. $935-955$
(C) Emerald Group Publishing Limited
$0959-0552$
DOI $10.1108 / 09590551211274937$ 
IJRDM

40,12

936

\section{Introduction}

Sustainability has become recognised as an important issue for UK clothing retailers during the last decade, with increasing demand from consumers for products which are environmentally and socially sustainable (Wrigley, 2008; Joergens, 2006; ASBCI, 2007; Carrigan and Atalla, 2001). Interest in sustainable clothing production and consumption is growing, as evidenced by sales of such clothing in the UK, which have demonstrated an upward trend in recent years, increasing by 93 per cent between 2007 and 2008, to achieve a market valued at $£ 172$ million per annum (Co-operative Bank, 2009). However, major fashion brands and retailers have garnered negative publicity and accusations that some of their products are manufactured in conditions which compromise social sustainability (Jones et al., 2009; BBC, 2008; Park and Lennon, 2006; Shaw et al., 2006; Klein, 2000). The clothing sector has responded to this type of publicity and to consumer demand, with the introduction of small-scale ethical clothing retailers and the launch of sustainable ranges by larger retailers, mainly based on organic cotton products or Fair Trade production.

The rapid increase in the size of the sustainable clothing market implies that consumers are concerned about sustainability, yet their actions can suggest otherwise (Shaw et al., 2006), thus creating an interesting tension. These issues indicate a requirement for research in this field, though only a limited number of studies have addressed this topic directly (for example, Hiller Connell, 2010; Allwood et al., 2006; Rudell, 2006; Iwanow et al., 2005; Carrigan and Atalla, 2001; Kim et al., 1999). The purpose of this paper is to investigate consumers' perspectives on the sustainability impacts of clothing and to examine ways in which this information could influence retailers' policies. The paper addresses the following research objectives:

- to identify current strategies towards sustainable clothing used by retailers;

- to establish consumers' views on potential measures to reduce the sustainability impacts of clothing manufacture, use and disposal; and

- to consider how these consumers' views could shape retail policy and practice.

Despite a growing awareness of sustainability and ethical issues, consumer behaviour is influenced by a variety of other factors, which this research seeks to identify and analyse. The study (Fisher et al., 2008) was commissioned by the UK Government's Department of the Environment, Farming and Rural Affairs (Defra). This paper seeks to evaluate the implications of the key findings from the Defra study and provides an overview of the main contemporary issues within the sustainable clothing market, in order to propose pragmatic strategies which could enable retailers to encourage ethical consumer behaviour in relation to sustainable clothing consumption.

\section{Sustainability and ethical consumption}

The World Commission on Environment and Development (Brundtland, 1987) produced a definition of sustainability which is widely quoted:

[...] development that meets the needs of the present without compromising the ability of future generations to meet their own need.

Ethical consumption is described by Jobber (2006, p. 217) as "the taking of purchase decisions not only on the basis of personal interests but also on the basis of the interests of society and the environment" and it is therefore closely connected with social and environmental sustainability. Sustainable and ethical consumption are consequently 
directly related concepts and the terms are often used interchangeably. Low and Davenport (2006, p. 324) stress the significance of ethical consumption, suggesting that ethical consumers could have "a role to play in changing the world". Nonetheless, various studies have shown that consumers who profess to hold ethical views often do not transfer their intentions into ethical purchase behaviour, thus forming a "values-action gap” (Markkula and Moisander, 2012; Carrington et al., 2010; Eckhardt et al., 2010).

Some of the key social and environmental sustainability issues in the clothing industry are: the increased volume of clothing consumption; employee working conditions and wages; pesticide use and disposal of used garments (Bianchi and Birtwistle, 2010; Birtwistle and Moore, 2007; Pretious and Love, 2006; Park and Stoel, 2005). The rise in ethical consumerism is illustrated by recent market research, with more than half of UK adults claiming to have made purchase decisions for ethical reasons in 2009, compared to one in four in 1999 (Co-operative Bank, 2009) and 35 per cent of adults in the UK being defined as "Green and Ethical Crusaders" by Mintel (2008). The impact of ethical issues on consumer purchases of clothing in the UK and Germany was investigated by Joergens (2006). She found that participants were aware of ethical issues concerning clothing manufacture and consumption, but that this did not usually affect their purchase behaviour, since the style and price of clothing were of more significance to them. Consumers within the same study felt that retailers did not provide enough information on labels about the source of the clothing to affect purchasing decisions. Similarly, Kim et al. (1999) examined the influence of socially responsible attitudes on consumers' purchase of clothing and found that consumers' desire to look individual was more influential than their attitudes towards social responsibility within clothing purchase decisions. Hustvedt and Dickson (2009) investigated a more specific aspect of ethical clothing consumption, i.e. the purchase of organic cotton clothing, in a survey of health food consumers. Their research revealed that the main motivation behind consumers purchasing organic cotton products was to support organic farming. This led the authors to suggest that organic farming and its environmental benefits should be promoted to consumers when marketing clothing made from organic cotton.

Although the media have brought the manufacturing and delivery aspects of sustainability to the fore, sustainability issues in relation to clothing extend well beyond the purchase stage and laundering is the aspect of clothing consumption which has the greatest impact upon the environment (Laitala et al., 2011; Allwood et al., 2006). It has been found that domestic laundering can be responsible for up to 82 per cent of the energy used during a garment's lifecycle (Fletcher, 2008). Laitala et al. (2011) tested the impact of laundering on various textiles and consequently they call for changes to consumers' laundering activities by reducing the volume of washing and tumble drying in order to address this concern. This is consistent with previous research which shows that consumers wash clothing more frequently than is necessary for hygiene or health (DAFI/BSR, 2012; Slater, 2003). UK clothing market leader Marks $\&$ Spencer $(M \& S)$ has tackled this issue with the introduction of the "Think Climate Wash at $30^{\circ} \mathrm{C}$ " label and there has recently been an "I do 30" campaign in Denmark (Marks \& Spencer, 2012; DAFI/BSR, 2012). Dombek-Keith and Loker (2011) suggest that a new set of wash-care symbols could be introduced to lower sustainability impacts, for example to encourage consumers to wash only in full loads. Another aspect of clothing maintenance is repair, yet consumers can be reluctant to extend the useful life of clothing in this way, due to lack of time and sewing skills, as well as the low cost of replacement (Gibson and Stanes, 2011).
The sustainable clothing market

937 
IJRDM

40,12

938
Disposal of clothing is another key sustainability issue, with high volumes of purchases fuelled by "fast fashion" (Bianchi and Birtwistle, 2010) resulting in approximately one million tonnes of clothes being discarded annually in the UK (Defra, 2009a). This may be due in part to the ease of disposing of clothes, as a US study found that many young consumers consider clothing recycling to be too inconvenient (Joung and Park-Poaps, 2012). In an attempt to counter this situation, Oxfam has collaborated with M\&S by offering store vouchers in exchange for donations of clothing and M\&S stores have recently begun to collect used clothing to be donated to charity (Oxfam, 2012). A more market-led approach to re-using clothing has been taken by the charity "Traid", by selecting garments from its recycling banks which are most appropriate for the customers at specific branches within its retail chain (Traid, 2012), a method which has also been applied by Oxfam to high-quality clothing donations.

With the aim of addressing the issues discussed above, in 2009 Defra used London Fashion Week as a vehicle to launch to the media and to fashion companies its "Sustainable Clothing Action Plan", a strategy designed to counter harmful impacts on the environment and society created through the production, use and disposal of clothing (Defra, 2009b).

\section{The sustainable clothing market}

Ethical consumerism has resulted in a market for ethical fashion which has been defined by Joergens (2006, p. 361) as "fashionable clothes that incorporate Fair Trade principles with sweatshop-free labour conditions while not harming the environment or workers, by using biodegradable and organic cotton". However, since many sustainable clothing ranges do not strictly meet all of these criteria, this paper uses a broader definition, to mean clothing which incorporates one or more aspects of social or environmental sustainability, such as Fair Trade manufacturing or fabric containing organically-grown raw material.

Sustainable clothing can fall into various categories, the main one being garments made from organic cotton, which is produced without pesticides. Though it makes up only 0.04 per cent of the global cotton market (Kooistra and Termorshuizen, 2006) organic cotton is the yarn used most frequently in the production of sustainable textiles and clothing, whereas conventional cotton farming is responsible for 11 per cent of the world's pesticide consumption, which can harm the environment. Clothing retailers such as casual wear brand Patagonia have sold clothing made from organic cotton, as well as other sustainable fabrics including fleece manufactured from recycled bottles. Another competitor in this market is American Apparel, which sells fashionable products made in the US from organic cotton, advertised as "sweatshop-free" and targeted at the youth market (Hyllegard et al., 2009).

Other methods of incorporating sustainability into clothing ranges have been adopted by various companies. For example, sports-influenced clothing brand Howies produces garments manufactured from recycled cotton yarn (Shepard, 2008). Another approach is referred to as "upcycling", demonstrated by designer range "From Somewhere", which incorporates pre-consumer waste from textile and garment manufacturers into its clothing designs (Holmes, 2008) and "Worn Again", a company which utilises post-use industrial waste in its products (Worn Again, 2011). Ethical knitwear label "Keep and Share" designs durable garments in styles which do not aim to follow mainstream fashion trends, therefore potentially lasting for longer than 
standard garments (Keep and Share, 2012). Some of this range is made from organic yarn and various products can be hired, to maximise their usage and avoid waste.

Traditionally, UK fashion retailers' marketing strategies have been largely price-led, combined with acceptable quality standards and fast turnaround (Mintel, 2009; Wong and Taylor, 2000), but it has become standard practice in recent years for them to offer a small selection of ethical clothing. Arnold (2009) makes the point that the ethical fashion industry consists mainly of small companies which therefore have low economies of scale, meaning that they struggle to compete with much larger, so-called "fast fashion" retailers. Despite increasing demand for ethical clothing and a prediction by Mintel (2007) that consumers will begin to move away from low quality clothing, consumers' appetite for fast fashion which is cheap, and therefore disposable, has not diminished, and therefore has an impact on sustainability issues. Turnover at low-priced retailer Primark has expanded rapidly in relation to its competitors, allowing it to rise to the position of third largest retailer by financial turnover in the UK fashion market (Mintel, 2009). Meanwhile, other High Street clothing retailers have launched ranges of ethical clothing in recent years. M\&S introduced Fair Trade cotton garments in 2006, followed by fashion multiples such as New Look and Monsoon selling organic cotton and Fair Trade garments respectively. It would therefore appear that cheap, disposable fashion and sustainable clothing can co-exist whilst simultaneously increasing in demand, even when being sold within the same retail outlet. However, the choice of clothing styles tends to be limited and formal workwear is particularly lacking in availability (Hiller Connell, 2010).

More than 95 per cent of garments purchased in the UK are manufactured offshore (Key Note, 2006) and, possibly as a consequence of this, consumers and the media are expressing more interest in the sources of clothing products (ASBCI, 2007). Several UK retailers have been criticised for selling garments from unethical producers, with supermarkets being accused in the media of using clothing factories which paid their clothing operatives $£ 0.07$ (sterling) per hour (BBC, 2008). This is indicative of the significant contrast between wages in developing countries and the Western hemisphere since clothing workers can earn the equivalent of US\$0.23 (£0.15) per hour in Pakistan, compared to typical earnings in the US of $\$ 11.16$ (£7.38) per hour (Wrigley, 2008).

In recent years, sustainable clothing has been the main theme of several trade and academic conferences (for example, ASBCI, 2007; The Textile Society, 2010), evidence of the fashion and textiles sector's attention towards this topic. Interest in ethical clothing has also been encouraged by non-government organisations (NGOs), aiming to persuade retailers (and therefore, ultimately, consumers) to buy ethically-manufactured clothing, including The Clean Clothes Campaign: an international organisation supporting clothing and footwear workers to improve working conditions (CCC, 2012) and its UK division, Labour Behind the Label (Labour Behind the Label, 2012). Researchers in Nordic countries have undertaken some of the key investigations into sustainable fashion and the Nordic Initiative Clean and Ethical (NICE), led by the Danish Fashion Institute, suggests that lack of information about sustainability impacts, difficulties in finding sustainable products, price barriers and style barriers hinder consumers from behaving in a more sustainable manner (DAFI/BSR, 2012). A UK-based industry body, the Ethical Trading Initiative (ETI) is an alliance of fashion retailers, aiming to improve ethical standards of clothing production (ETI, 2012). This is consistent with a report on Ethical and Green Retailing by Mintel (2008) which suggests that a "unified industry response" would be more beneficial than companies reacting to sustainability issues individually. However, in
The sustainable clothing market 
IJRDM

40,12

940

certain cases, retailers' interest in ethical issues, demonstrated by their membership of the ETI, could be in response to media coverage of unethical behaviour in the fashion business and increasing ethical consumerism.

\section{Fair Trade products}

Fair Trade is another category of sustainable clothing. Fair Trade is defined by FINE, an international alliance of Fair Trade organisations, as "a trading partnership, based on dialogue, transparency and respect, that seeks greater equity in international trade" (FINE, 2001, p. 1). The Fair Trade Foundation describes its consumer label as "an independent guarantee that disadvantaged producers in the developing world are getting a better deal" (Fair Trade Foundation, 2012). Despite increasing sales volumes, Fair Trade companies have been criticised for their inadequate promotional strategies and the low level of consumer awareness of the Fair Trade federation's logo (Wright and Heaton, 2006; Littrell et al., 2005). However, other research has identified an increase in consumers' and industry insiders' awareness of socially responsible companies (Halepete and Park, 2006). There have been various studies about the market for Fair Trade products in general, yet research into the relationship between Fair Trade and clothing is relatively limited (for example, Halepete et al., 2009; Halepete and Park, 2006; Shaw et al., 2006; Littrell et al., 2005; Littrell and Dickson, 1998). Strong (1997) investigated consumer behaviour in relation to Fair Trade products and concluded that, whilst consumers considered environmental sustainability to be a global responsibility, people may be less concerned about social sustainability, since they consider this to be the responsibility of individual countries. Though Strong's study was published prior to the availability of Fair Trade clothing in the UK her conclusion could partially explain its slow rate of adoption by consumers. Fair Trade fashion was estimated to be worth $£ 5$ million in Great Britain in 2006 , representing a very small proportion of a total clothing market worth $£ 39$ billion (Key Note, 2009). Consequently, the Fair Trade Foundation hopes to increase the proportion of Fair Trade cotton garments sold in the UK to 10 per cent of the cotton clothing market by 2012 (BBC News, 2009).

\section{Retailers' sustainability policies}

Whilst consumers undoubtedly have an impact on sustainability issues, Jones et al. (2010, p. 256) also acknowledge the substantial impact of retailers, stating that "large retailers have a pivotal role to play in promoting sustainability in that they are the intermediaries between primary producers and manufacturers on the one hand and customers on the other". Retailers' approaches towards sustainability issues can be indicated by the implementation of corporate social responsibility (CSR) policies. The potential advantages of CSR to organisations include: reduced operating costs (for example by using renewable sources), enhanced brand image and new marketing opportunities (Jobber, 2006). Additionally, Wright and Heaton (2006) claim to have established a link between CSR and improved business performance. However, Ellis and Higgins (2006) dispute the effectiveness of CSR policies, since such policies cannot guarantee the existence of "fairer" trade. Webley and Werner (2008) concur with this view, identifying the potential existence of a gap between intention and operation in relation to companies' codes of ethics and recognising that codes of ethics in themselves do not ensure that organisations behave ethically. Dickson's (2005, p. 15) perspective on CSR is that "social responsibility is reflected in a continuum of practices" by companies, 
varying from "minimal efforts" to "more comprehensive and long-term practices", thus indicating a wide variation in the degree of implementation of CSR by different organisations. Elkington (2004) coined the phrase "triple bottom line" to acknowledge the significance of environmental and social concerns to businesses, in addition to financial sustainability (Fisher and Lovell, 2009). However, it has proven difficult to report on the social and environmental aspects, due to their lack of tangibility (Henriques and Richardson, 2004) and life cycle assessment has emerged as a framework to assess the impact of products on the environment (Jørgensen et al. 2008).

Carrigan and Atalla (2001) question the potential commercial viability of companies' ethical behaviour, though growing consumer awareness of ethical issues since the publication of their study may explain the different perspective from more recent research. For example, Moon et al. (2009, p. 269) claim that CSR "increases intangible benefits" and confers "modest financial benefits" on companies. Jones et al. (2010) found that most of the world's top ten largest retailers produce sustainability reports. However, they posited that these retailers' sustainable actions are likely to be prompted more by gaining efficiencies than by ecological issues and these organisations are not addressing the overriding issue that current consumption patterns are unsustainable.

Research into sustainability in relation to clothing retailers focuses largely on ethical sourcing and ethical consumption. In response to the trend towards ethical consumption, it has become an established practice for retailers to publish CSR policies or codes of conduct (Nichols, 2002; Jones and Comfort, 2005; Cathcart, 2006) which impact upon retailers' garment sourcing and partnerships with suppliers. However, the implementation of such policies in practice can be questionable. Fashion retailers do not usually manufacture the merchandise they sell, preferring instead to sub-contract production to manufacturers whilst retaining marketing and sales in-house (Goworek, 2007). Consequently, various clothing retailers have sought to address sustainability by appointing managers within quality or technology teams who are responsible for developing and implementing CSR policies and monitoring systems for ethical sourcing of the company's products (ASBCI, 2007).

Pretious and Love (2006) investigated UK clothing retailers' codes of conduct and concluded that the guidelines for ethical purchasing compiled by most of the retailers in their study indicated that the companies were committed to clothing workers' welfare. In the USA, fashion companies can place their factory audits on the American Fair Labor Association website to make their supply chains more transparent and to potentially prevent adverse publicity (Bernstein, 2003, cited in Rudell, 2006). People Tree and Levi Strauss take this practice a stage further by offering consumers information on specific suppliers which manufacture their products on the companies' websites (People Tree, 2012; Levi Strauss, 2012). An alternative approach is adopted by "Made-By", a Netherlands-based not-for-profit organisation, offering an ethical label and support to its licensees, allowing them to audit the sustainability of their production (Made-By, 2012). Choice editing by retailers, so that customers are offered only sustainable options of certain product types, is another method of encouraging sustainable consumer behaviour. For example, supermarket chain Sainsbury's implemented choice editing by upgrading its standard T-shirts, selling only garments manufactured from Fair Trade cotton (Kilgallen, 2007).

In summary, the literature provides a variety of evidence of increasing demand for ethical fashion, with participation in this area from NGO's, the Government, academics, retailers and consumers, indicating a potential need for further research into this topic. 
IJRDM

40,12

942
Figure 1.

Illustration of methodology
Figure 2.

Participants by segment, age and gender (all locations)

\section{Methodology}

Defra provided the funding for this study and specified the use of qualitative research, which is particularly suited to the purpose, since it explores consumers' attitudes and behaviour (Bryman and Bell, 2011). Qualitative research was conducted using a three-stage process: focus groups, home tasks and workshops with consumers, between March and July 2008 (Figure 1).

For the first stage 99 respondents were recruited from Manchester, Nottingham and St Albans by on-street interviewers, to represent the Northern, Midland and Southern regions of the UK. The sample group represented different groups of consumers in relation to their sustainability behaviour, from those who did not consciously participate in sustainable practices to those at the opposite extreme who could be described as "positive greens", as defined by Defra's Environmental Segmentation Model (Defra, 2008). The respondents were screened to ensure an even spread of age, gender and socio-economic group (Figure 2).

Nine focus groups (three in each location) discussed a variety of issues regarding the sustainability of clothing, from purchase decisions through to laundering and disposal. Within the discussion groups, participants were informed about various sustainability issues relating to clothing. A total of 29 individuals from these groups were then selected and requested to conduct an audit of three garments from each respondent's wardrobe. This stage was followed by deliberative workshops (one in each of the three locations) with the same 29 participants, to examine the outcomes of these activities in relation to sustainability, incorporating discussions about how their views and behaviours in relation to purchase, use and disposal of clothing could change as a result of receiving this information. Representatives from retailers and other organisations from Defra's

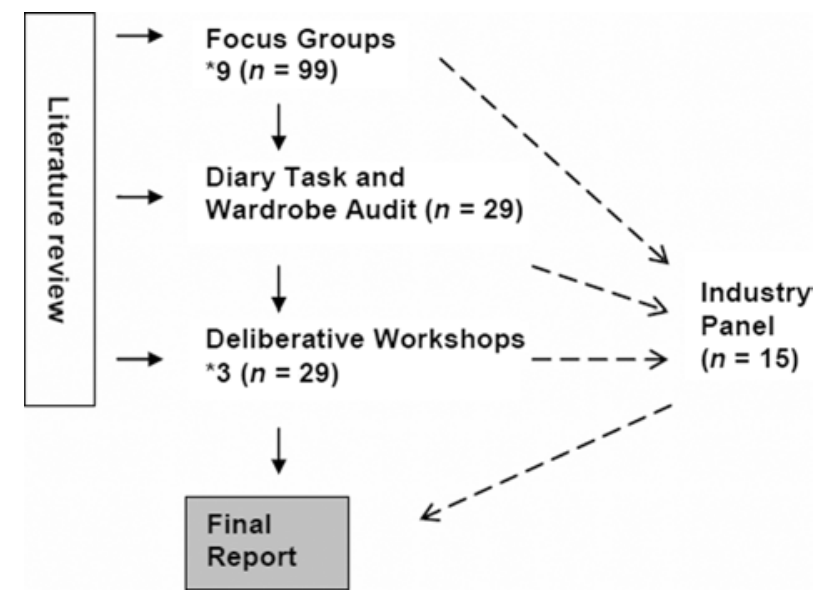

\begin{tabular}{|cccccccc}
\hline Segment & S1 & S2 & S3 & S4 & S5 & S6 & S7 \\
$n=$ & 13 & 11 & 19 & 12 & 17 & 14 & 13 \\
\hline Age & $18-25$ & $26-45$ & $46-65$ & & & & \\
$n=$ & 26 & 45 & 28 & & & & \\
\hline Gender & M & F & & & & & \\
$n=$ & 57 & 42 & & & & & $n=99$ \\
\hline
\end{tabular}


Clothing Roadmap Stakeholders Group, were invited to a meeting with Defra, to be informed of the initial research outcomes and to discuss these issues in relation to their own organisations' stances towards ethical clothing (Defra, 2012).

\section{Findings}

\section{Consumers' attitudes towards sustainable clothing}

The findings from the Defra study about consumers' perspectives on sustainable clothing which are most relevant to clothing retailers are discussed here. A key finding was that the focus group participants had a limited awareness of the sustainability impacts of clothing. Even the environmentally-aware respondents in the sample group made purchase decisions influenced primarily by economic and personal factors, as well as being based on sustainability. Many respondents bought low-priced clothing from "value retailers", despite being aware of the potential environmental impact of their actions and the fact that this clothing was unlikely to be durable. Where participants displayed pro-environmental behaviour, this was not necessarily intentional, but was largely a response to other influences. For example, respondents were aware that washing at lower temperatures than recommended on labels was more environmentally-friendly, but some were reluctant to reduce the temperature or frequency of washing. Though washing clearly takes place after consumers' interaction with retailers, this is nevertheless an area where retailers could exert some influence and this is a crucial area for change in consumer behaviour. Indeed, retailers that sell detergents or washing machines could have a greater influence here than clothing retailers. The respondents' maintenance and disposal of clothes were found to be influenced mainly by existing habits and routines, which appeared to take precedence over awareness of sustainable practice. Consumers' views specifically on laundering were not uncovered in the literature search, but this finding is compatible with Joergens's (2006) and Kim et al.'s (1998) findings that ethical issues are not usually consumers' main priority when purchasing clothing. This finding also supports recommendations by Laitala et al. (2011) that consumer laundering habits have potential for improvement in terms of sustainability.

\section{Organic and Fair Trade clothing}

Some participants expressed scepticism and mistrust towards retailers' motives and honesty in offering environmentally friendly and Fair Trade clothes, demonstrated by this comment from a focus group participant:

A label is nothing, it doesn't mean anything ... We need proof of it.

Some felt that sustainable clothing was too expensive, with ten pounds being considered by one respondent to be too much to pay for a white organic cotton T-shirt. Though sustainable clothing ranges are becoming increasingly available, many participants were not aware that retailers stocked such ranges and some were not familiar with organic cotton clothing, thereby preventing them from purchasing these types of product. For example, one participant pleaded:

You talked about Fair Trade clothing: where is it? If you're talking about consumer power, at least give us the tools to be able to choose. Give us the information.

Another participant supported this view by suggesting that consumers should be provided with more information about Fair Trade and the impact of pesticides, to help
The sustainable clothing market 
IJRDM

40,12

944 people to change their opinions towards sustainable clothing. Though this information is available from academic sources and pressure groups, this does not appear to have filtered through to many mainstream consumers who participated in this study, supporting Wright and Heaton's (2006) conclusion that consumer awareness of Fair Trade products is limited. This is also consistent with findings by DAFI/BSR (2012) that lack of information about sustainable clothing is a key barrier to consumer action. Some of the respondents in this study questioned why governments permitted the sale of any clothing which was not Fair Trade and there were suggestions that the clothing industry should share responsibility with the Government for this. One participant advocated that a market leader should make all of its products both organic and Fair Trade and another requested that all clothing retailers should do this.

\section{Longevity and disposal of clothing}

Predictably, some participants often bought cheap clothing, despite being aware that it was unlikely to be long-lasting, due to low quality standards and its short-term fashionability. Consumers in the study tended to perceive well-made, long-lasting clothing as being good quality, rather than viewing it as being sustainable, assessing the quality standard by the "feel" of the clothing and its brand. In contrast, cheap clothes were considered by many to be disposable, with frequent reference to a large value retailer. One respondent reported purchasing 16 tops from this store to take on holiday, then discarding them before returning home and another referred to cheap garments as "throwaway clothes", exemplifying the views towards low-priced merchandise of many others in this study. Respondents' knowledge of recycling facilities was limited and therefore the lack of recycling amongst the focus groups was not necessarily based on a lack of concern or unwillingness to dispose of garments via sustainable methods. For example, one participant stated: "Nobody says "bring your old clothes back so we can recycle them', there [are] no adverts" and another commented: "You don't know about it, so you don't know that you're doing anything wrong". One focus group member proposed that retailers could offer a scheme to take back clothes after use, resembling the Waste Electronic and Electrical Equipment directive which makes UK retailers responsible for accepting used electrical goods from consumers for recycling. These comments lend support to M\&S's more recent decision to collect clothing for Oxfam in its stores.

Overall, the comments from the focus groups in relation to consumers' repair and disposal of clothing were consistent with the findings of previous research on this topic by Birtwistle and Moore (2007). The study found that some of the participants occasionally used repair services offered by dry-cleaners, but that this option was considered to be too expensive by many of them. Most participants did not carry out clothing repairs themselves, though some had older female relatives who did this for them. Donating used clothing deemed to be of a suitable standard to charity shops and using recycling facilities or passing them on to friends and family were common practices amongst the participants. Many participants disposed of clothes with refuse, particularly when garments were cheap and considered to be of poor quality. This comment from a participant reflects the impact of the widespread availability of cheap, low-quality clothing in the UK during recent years:

You tend to buy clothes and not to keep them so long [...] years ago, you used to buy something, you'd keep it for five years and then if it needed a repair you'd do something to it, but these days [...] I think clothes are cheaper and you just get fed up with them. 
Influencing consumer behaviour towards sustainability

The study found consumers' decisions on clothing purchases to be influenced by information at the point-of-sale, as well as by the media, and this approach was particularly prevalent amongst the younger respondents. Some of the participants were willing to consider altering this type of behaviour in response to government interventions or increased information about the sustainability of clothing consumption. This is consistent with the recommendation by DAFI/BSR (2012) that increased communication to consumers by retailers could help to overcome barriers to acting sustainably. However, even when the respondents were aware of some of these sustainability issues, they did not necessarily act upon them. Virtually all of the 29 participants involved in the second stage of the research (the diary and wardrobe audit tasks conducted at home) changed aspects of their behaviour towards clothing. It is possible to see how the information and discussions from the initial focus groups affected their subsequent behaviour. The most significant behavioural change was in laundering, with more than a third engaging in more environmentally-friendly activity by reducing energy usage, such as reducing washing temperatures and frequency or minimising tumble-drying. A smaller proportion of the group planned to alter their shopping habits, intending to act more sustainably by purchasing less clothing and selecting organic cotton or Fair Trade garments.

In summary, the Defra study found that the respondents' attitudes towards clothing were affected by numerous factors, including concerns in relation to sustainability, and that their behaviour could be altered after they were provided with relevant information.

\section{Views of retailers and other stakeholders}

The preliminary findings of the research were presented to Defra's stakeholder group, prompting discussion on various issues. One of the outcomes of this discussion was that representatives of smaller companies producing sustainable clothing were willing to support larger retailers and the Government with advice on the development and implementation of sustainable clothing ranges, by operating on a consultancy basis. The same participants suggested that consumers could be encouraged to increase the longevity of clothing by purchasing fewer items, which would have lasting design appeal and durability. The larger retailers in the stakeholder group focused on the need to agree a specific definition of sustainability in order to establish consistent standards and accreditation for clothing which is produced sustainably.

\section{Discussion}

The aim of this paper is to investigate consumers' perspectives on the sustainability impacts of clothing and to examine ways in which this information could influence retailers' policies.

The research findings were evaluated to review the potential pragmatic strategies which could be implemented to improve the sustainability impacts of the clothing sold by retailers. The study indicated that consumers could be persuaded to change their behaviour in relation to sustainability by being encouraged and enabled to reflect more on their behaviour, as the participants did during the home tasks and subsequent workshops. It could therefore be possible for retailers to offer sustainability guidelines for their customers to reflect and act upon, thus helping to alter ingrained habits in terms of purchase, wear, laundering and disposal of clothing. Such tactics would be
The sustainable clothing market

945 
IJRDM

40,12

946 likely to generate costs for the retailers concerned, but many could be implemented at relatively low cost, for example if disseminated via company websites and the use of QR codes in stores. Retailers within the stakeholder group discussed setting consistent sustainability standards among different companies. This could allow them to improve their policies and practice towards sustainability, possibly via a collaborative industry body, to enable positive social and environmental changes to be made. Techniques which retailers could implement to improve the sustainability impacts of clothing are discussed next, based on a synthesis of the primary research and relevant literature.

\section{Choice editing}

Editing the choice of sustainable products available to consumers in their stores, as implemented by Sainsbury's (Kilgallen, 2007), could allow retailers to reduce the sustainability impacts of their merchandise. Clothing retailers could edit the choices available to their customers by offering products either manufactured from sustainable textiles, such as organic cotton or wool, or produced by Fair Trade garment manufacturers, in place of existing products. Alternatively, retailers could take a strategic decision to change the kind of products that they sell, supplying longer-lasting clothing, as suggested within the stakeholder group. This approach could enable more consumers to enhance their sustainable behaviour towards clothing at the acquisition stage. By suggesting that stores could sell only clothing which was Fair Trade or organic, certain focus group participants indicated that choice editing was a retail strategy which they considered to be acceptable.

\section{Use of environmentally and socially sustainable textiles}

Since pesticides contaminate the soil, as well as endangering cotton producers' health, a decision by retailers to supply more products containing organic cotton could improve both environmental and social sustainability, via the removal of pesticides from the farming process. The environmental benefits of organic farming could be communicated to customers, as proposed by Hustvedt and Dickson (2009). However, organic cotton is in limited supply, in part because of the lower yield inherent in organic farming methods. Consequently, higher retail prices need to be charged for organic cotton products, unless lower margins are accepted, thus affecting the financial sustainability of using this fibre. A further drawback is that standard cotton prices have substantially inflated due to worldwide shortages, thereby increasing the selling price of cotton garments (NCC, 2012; Rushton, 2010; Vulser, 2010). Mass market consumers may therefore be unwilling or unable to pay an additional premium for clothing produced from organic cotton and consequently garments could be manufactured from other types of sustainable fibre. For example, Laitala et al. (2011) advocate the use of wool in preference to cotton, though this too can be relatively expensive. The ranges of organic cotton products launched by clothing retailers since 2006 demonstrate the viability of offering such products at mass market price points. As the research findings indicate that many consumers are unaware of the availability of sustainable clothing and Joergens's (2006) study also suggests that labelling could be made more prominent, this is an area which could be improved by retailers, with the potential to offer more extensive promotion beyond the in-store environment (DAFI/BSR, 2012). Due to retailers' commercial interests, many consumers may be sceptical and mistrustful of the sincerity of labels (Hanss and Böhm, 2012), so a consistent verification system could be used, preferably from an independent source. Methods of enhancing sustainability used by ethical clothing companies are to 
manufacture clothes using recycled cotton yarn (Shepard, 2008) or pre-consumer waste fabric (Holmes, 2008), thus avoiding the increased costs associated with newly-produced organic cotton, or to rent clothing to consumers (Keep and Share, 2012), to maximise its use before disposal. These alternative approaches to sustainable textile usage have the potential to be utilised further by retailers.

Fair Trade and socially sustainable manufacture

The study indicated that once better informed of poor conditions in the clothing supply

The sustainable clothing market chain, consumers are more likely to consider purchasing Fair Trade products, if they can find out where to purchase them. Consumer awareness of social sustainability issues which affect clothing production has increased, fuelling the demand from consumers for transparency in the clothing supply chain, as requested by focus group participants in this study. A potential response to this by fashion retailers would be to communicate information to customers on the suppliers used for particular garments, as implemented by People Tree (2012) and Levi Strauss (2012). Understandably, this may be viewed as a disadvantage by retailers which prefer to keep their sources confidential in order to avoid their suppliers' production capacity being acquired by competitors. Also, the types of garment which are manufactured sustainably could be expanded upon, to offer the consumer a wider choice of formal, as well as informal, ethical clothing (Hiller Connell, 2010).

\section{Laundering clothes}

The study showed that consumers viewed the main sustainability issue related to clothing to be at the manufacturing stage. However, laundering clothes has a greater impact upon the environment (Laitala et al., 2011; Allwood et al., 2006). The research found that participants were reluctant to wash clothing at low temperatures though, in case this compromised cleanliness. This suggests that retailers could help consumers to improve sustainability impacts in the laundering of clothing, again by making the information on the labels of their products more prominent and explicit, to dispel consumers' concerns about washing temperatures, as M\&S has done. Supplementary information could potentially be provided with garments, such as the average energy usage when washing at different temperatures. The economical nature of washing clothes at lower temperatures and avoiding tumble-drying could also be stated on labels, as proposed by Dombek-Keith and Loker (2011), since this study showed that sustainable behaviour is often a by-product of other factors which are considered to be more important to consumers. It should be noted, however, that the production of additional labelling could add to the sustainability impact of the retailer.

\section{Repair of clothes}

A low proportion of the focus group participants had sewing skills and, as the findings show, this can contribute towards the frequent disposal of clothes which could have been repaired relatively easily. Price deflation in the UK clothing market (Grimston and Smith, 2003) has led consumers to view clothes as disposable items, for which professional repair is rarely a cost-effective option, according to the findings. Clothing retailers could therefore address this issue, for example by offering in-house repair services, if this could be subsidised to make it cost-effective for customers to use. The value of such a service to retailers could be primarily as a component of CSR policy and the positive publicity surrounding it, rather than being a profit-making venture in itself. Guides to repairing clothing and kits to enable consumers to do this could be 
IJRDM

40,12

948 offered by retailers, from the companies' websites or via smartphone apps. There is potential for short courses in clothing repair and maintenance to be offered by universities and colleges throughout the UK, with content and advertising sponsored by, or approved and promoted by fashion retailers.

\section{Disposal of clothes}

The research revealed concern among participants about the waste created by their clothing purchases, in common with the findings of Bianchi and Birtwistle (2010), yet a lack of knowledge regarding the facilities available to enable them to adopt more sustainable practices. To avoid consumers' routine disposal of clothing with refuse, guidelines about the impact on the environment of clothing disposal could potentially be offered by retailers, featuring clear information about disposal routes and their implications for the environment. An option to address this situation could be to locate containers within the communal areas of shopping centres to collect clothing for recycling.

Retail chains could form partnerships with charities to facilitate the re-use of second-hand clothing, following the examples of Oxfam and Traid. Retailers have the opportunity to take advantage of the popularity of "vintage" clothing by selecting and purchasing relevant items from clothing donated to charities, or directly from consumers, thus contributing to both environmental and social sustainability. However, the practicalities and cost implications of attaining and selecting sufficient quantities of garments of suitable quality and design are potential barriers to retailers adopting this strategy on a large scale. Other options could be explored to encourage more sustainable disposal of clothing (Birtwistle and Moore, 2007), for example, stores or retailers' websites could be used as locations for clothes-exchange events amongst consumers.

\section{Conclusion}

Clothing retailers have a significant role to play in relation to sustainable clothing (Jones et al., 2010) and they are uniquely positioned to be able to influence and improve consumers' approach to the sustainability of clothing. Current strategies towards sustainable clothing used by retailers have been identified within this paper, with a tendency for small ethical clothing brands, at one end of the spectrum, and market leading retailers, at the other, to implement such strategies. There is consequently much potential for more retailers of all sizes to offer sustainable clothing ranges, with the possible advantages of corresponding benefits, including reduced operating costs, enhanced brand image and new marketing opportunities (Jobber, 2006).

Consumers' views on potential measures to reduce the sustainability impacts of clothing manufacture, use and disposal were established via the discussion groups. These views included requests for more information on the sustainability impacts of clothing in terms at purchase, use and disposal stages, consistent with the recommendations of DAFI/BSR (2012). The views of consumers in the study could shape retail policy and practice in various ways, via the provision of sustainable clothing and information concerning this. Clothing retailers can select and develop their own blend of outcomes, dependent upon financial, temporal and political constraints, in response to consumers' views, evidenced by the compilation and practical implementation of CSR policies. By adopting more sustainable strategies, depending on their viability for target customers, this retail sector's reputation for social and environmental sustainability could be enhanced. 
Increasing consumers' knowledge of sustainability, with a view to improving their sustainable practice towards clothing, could be facilitated by Governments and by the retailers who supply this clothing to the public, potentially in collaboration with the mass media. Since participants changed their behaviour after information about sustainable practice was presented to them in the focus groups, this suggests that education from the Government, NGO's or commercial sources has the potential to elicit a positive impact on consumers' sustainable behaviour. A barrier to the implementation of sustainable practices by retailers could be the perception of a clothing market conflict with companies' profitability, and it is therefore important that ethical strategies are compatible with financial strategies, taking into account the triple bottom line.

Retailers have a selection of techniques available to them to use in policy and practice to improve sustainability impacts: choice editing, using environmentally and socially sustainable textiles, Fair Trade and other forms of socially sustainable clothing manufacture. Retailers could be considered to have environmental and social responsibilities throughout the lifecycle of clothing, including the post-purchase and divestment stages, rather than just to the point of purchase, and consequently they have a significant opportunity to influence consumers' sustainability impacts when laundering, repairing and disposing of clothes.

\section{Recommendations}

The formation of an organisation to debate sustainability issues and to formulate strategies for the sector could be instigated, possibly facilitated by government support. This would enable retailers to set consistent standards for sustainability to which members could adhere. Existing industry bodies, such as the ETI, could be the starting point for such collaboration between retailers. A team of staff from various retailers, such as CSR managers, could potentially collaborate on developing information about sustainability for consumers, in line with Mintel's (2008) suggestion that a "unified industry response" would be beneficial in reaction to sustainability issues. As suggested in the stakeholder meeting, ethical fashion retailers and brands with expertise in sustainable clothing could potentially act in a consultative capacity to some of the larger retailers to inform policy and practice in relation to sustainability. Clothing suppliers and manufacturers could also participate, to provide technical expertise and to enhance their own awareness of sustainability issues in the sector.

Consumers in this study called for the UK Government and retail market leaders to take responsibility for improving sustainability in the clothing sector. Although the Government could be instrumental in regulating the industry, this study shows that consumers acquire much of the information regarding their clothing purchases in the store environment, and retailers therefore have the capacity to influence the public at the point of purchase. Government support could assist in facilitating such developments, building upon its instigation of a Sustainable Clothing Action Plan (Defra, 2010) drawing together stakeholders from retailing, manufacturing, textile disposal and higher education.

\section{Implications}

The findings of this study have implications for retailers, academics and society. Retailers can develop and implement more sustainable policies and practices in relation to clothing production and consumption. There is potential for academics to conduct 
IJRDM

40,12

further research and generate theories which apply to the sustainability of clothing, building on previous research in this field, as well as disseminating information about sustainable clothing consumption requested by the study's participants. There are wider implications for society and the environment in that retailers' sustainable practices can contribute positively to sustaining the planet's resources.

\section{Limitations}

Limitations of this study are that it uses only qualitative research and is limited to UK consumers. Future research in this field could incorporate quantitative methods or in-depth interviews with consumers in the UK, as well as in other countries. Retailers' views could also be sought about the practicalities of implementing strategies to reduce the social and environmental impact of clothing consumption. This study has concentrated on consumers' and retailers' sustainability impacts and future research could be conducted from the perspective of clothing manufacturers, who also have a major role to play.

\section{Acknowledgements}

Funding for this study was provided by the UK Government's Department of the Environment, Farming and Rural Affairs (Defra) in order to ascertain public understanding of sustainable clothing. The authors would like to thank their colleagues Dr Carley Foster and Professor Kim Cassidy for providing valuable feedback on drafts of this article and the anonymous reviewers who helped to strengthen the content with their constructive recommendations.

\section{References}

Allwood, J.M., Laursen, S.E., de Rodriguez, C.M. and Bocken, N.M.P. (2006), Well Dressed? The Present and Future Sustainability of Clothing and Textiles in the UK, Cambridge University Institute of Manufacturing, Cambridge.

Arnold, C. (2009), Ethical Marketing and the New Consumer, John Wiley \& Sons, Chichester.

ASBCI (2007), "Publications: conference papers May 2006 and May 2007", available at: www. asbci.co.uk/Pub-conference.htm (accessed 26 May 2011).

BBC (2008), "UK clothes chains 'abuse workers", BBC News, 5 December, available at: http:// news.bbc.co.uk/1/hi/business/7767106.stm (accessed 1 May 2011).

BBC News (2009), "Bid to buck fast fashion trend", 20 February, available at: http://news.bbc.co. uk/1/hi/uk/7899327.stm (accessed 26 May 2011).

Bernstein, A. (2003), "Sweatshops: finally, airing the dirty linen", Business Week, 23 June, pp. 100-2.

Bianchi, C. and Birtwistle, G. (2010), "Sell, give away, or donate: an exploratory study of fashion clothing disposal behaviour in two countries", The International Review of Retail, Distribution and Consumer Research, Vol. 20 No. 3, pp. 353-68.

Birtwistle, G. and Moore, C.M. (2007), "Fashion clothing - where does it all end up?", International Journal of Retail \& Distribution Management, Vol. 35 No. 3, pp. 210-6.

Brundtland, G.H. (1987), "Our common future", Report of the World Commission on Environment and Development, available at: www.un-documents.net/ocf-01.htm

Bryman, A. and Bell, E. (2011), Business Research Methods, 3rd ed., Oxford University Press, Oxford. 
Carrigan, M. and Atalla, A. (2001), "The myth of the ethical consumer; do ethics matter in purchase behaviour?", Journal of Consumer Marketing, Vol. 18 No. 7, pp. 560-78.

Carrington, M.J., Neville, B.A. and Whitwell, G.J. (2010), "Why ethical consumers don't walk their talk: towards a framework for understanding the gap between the ethical purchase intentions and actual buying behaviour of ethically minded consumers", Journal of Business Ethics, Vol. 97, pp. 139-58.

Cathcart, A. (2006), "A quite unreasonable state of affairs: corporate social responsibility and the John Lewis Partnership”, Social Responsibility Journal, Vol. 2 No. 2, pp. 201-6.

CCC (2012), "Clean Clothes Campaign”, available at: www.cleanclothes.org/ (accessed 24 March 2012).

Co-operative Bank (2009), ), "The ethical consumerism report", available at: www. goodwithmoney.co.uk/ethicalconsumerismreport/ (accessed 25 May 2011).

DAFI/BSR (2012), "The NICE consumer research summary and discussion paper", Danish Fashion Institute/BSR, available at: www.bsr.org/reports/BSR_NICE_Consumer_ Discussion_Paper.pdf (accessed 4 May 2012).

Defra (2008), “A framework for pro-environmental behaviours", www.defra.gov.uk/evidence/ social/behaviour/index.htm (accessed 29 April 2011).

Defra (2009a), "Maximising reuse and recycling of UK clothing and textiles", available at: www. defra.gov.uk/environment/business/products/roadmaps/clothing/documents/reuserecycling.pdf (accessed 30 April 2011).

Defra (2009b), "Sustainable clothing action plan launched at London Fashion Week", Defra news release, 20 February, available at: www.defra. gov.uk/news/2009/090220a.htm (accessed 30 April 2011).

Defra (2010), “A more sustainable future for fashion”, available at: http://sd.defra.gov.uk/2010/ 03/sustainable-future-for-fashion/ (accessed 30 April 2011).

Defra (2012), "Product roadmaps: clothing", available at: www.defra.gov.uk/environment/ business/products/roadmaps/clothing/index.htm (accessed 25 April 2012).

Dickson, M.A. (2005), "Profiling apparel label users", in Harrison, R., Newholm, T. and Shaw, D. (Eds), The Ethical Consumer, Sage, London, pp. 155-71.

Dombek-Keith, K. and Loker, S. (2011), "Sustainable clothing care by design", in Gwilt, A. and Rissanen, T. (Eds), Shaping Sustainable Fashion, Earthscan, London, pp. 101-18.

Eckhardt, G.M., Belk, R. and Devinney, T.M. (2010), "Why don't consumers consume ethically?", Journal of Consumer Behaviour, Vol. 9, pp. 426-36.

Elkington, J. (2004), "Enter the triple bottom line", in Henriques, A. and Richardson, J. (Eds), The Triple Bottom Line: Does It All Add up? Assessing the Sustainability of Business and CSR, Earthscan, London, pp. 1-16.

Ellis, N. and Higgins, M. (2006), "Recatechizing codes of practice in supply chain relationships: discourse, identity and otherness", Journal of Strategic Marketing, Vol. 14 No. 4, pp. 387-410.

ETI (2012), "Ethical Trading Initiative", available at: www.ethicaltrade.org/Z/home/index.shtml (accessed 25 March 2012).

Fair Trade Foundation (2012), "What is fair trade?", available at: www.Fair Trade.org.uk/what_is_Fair Trade/default.aspx (accessed 25 March 2012).

FINE (2001), "Fair trade definition and principles", available at: www.befair.be/site/download. cfm?SAVE=1314\&LG=1-FINE definition (accessed 25 May 2011).

\section{The sustainable clothing market}

951 
IJRDM

40,12

952
Fisher, C. and Lovell, A. (2009), Business Ethics and Values: Individual, Corporate and International Perspectives, 3rd ed., Financial Times/Prentice Hall, London.

Fisher, T., Cooper, T., Woodward, S., Hiller, A. and Goworek, H. (2008), "Public understanding of sustainable clothing: a report to the Department for Environment, Food and Rural Affairs", Defra, London, available at: http://randd.defra.gov.uk/Default. aspx?Menu $=$ Menu\&Module $=$ More\&Location $=$ None\&Completed $=0 \&$ ProjectID $=15626$ (accessed 29 April 2011).

Fletcher, K. (2008), Sustainable Fashion and Textiles: Design Journeys, Earthscan, London.

Gibson, C. and Stanes, E. (2011), "Is green the new black? Exploring ethical fashion consumption", in Lewis, T. and Potter, E. (Eds), Ethical Consumption: A Critical Introduction, Routledge, London, pp. 169-85.

Goworek, H. (2007), Fashion Buying, 2nd ed., Blackwell Publishing, Oxford.

Grimston, J. and Smith, D. (2003), "Prices in Britain lowest for 15 years", The Times, 20 July.

Halepete, J. and Park, J. (2006), "Competitive e-tailing strategies for Fair Trade organizations", Journal of Fashion Marketing and Management, Vol. 10 No. 4, pp. 491-507.

Halepete, J., Littrell, M. and Park, J. (2009), "Personalization of Fair Trade apparel: consumer attitudes and intentions", Clothing and Textiles Research Journal, Vol. 27 No. 2, pp. 143-60.

Hanss, D. and Böhm, G. (2012), "Sustainability seen from the perspective of consumers", International Journal of Consumer Studies, available at: doi: 10.1111/j.1470-6431.2011.01045.x. (accessed 23 March 2012).

Henriques, A. and Richardson, J. (2004), The Triple Bottom Line: Does It All Add up?? Assessing the Sustainability of Business and CSR, Earthscan, London.

Hiller Connell, K.Y. (2010), "Internal and external barriers to eco-conscious apparel acquisition", International Journal of Consumer Studies, Vol. 34 No. 3, pp. 279-86.

Holmes, R. (2008), "From nowhere to somewhere", The Guardian, 14 November, available at: www.guardian.co.uk/lifeandstyle/2008/nov/14/ethical-fashion-from-somewhere (accessed 25 May 2011).

Hustvedt, G. and Dickson, M.A. (2009), "Consumer likelihood of purchasing organic cotton apparel: influence of attitudes and self-identity", Journal of Fashion Marketing and Management, Vol. 13 No. 1, pp. 49-65.

Hyllegard, K., Ogle, J. and Yan, R.N. (2009), "The impact of advertising message strategy - fair labor versus sexual appeal - upon Generation Y consumers' intent to patronize an apparel retailer", Journal of Fashion Marketing and Management, Vol. 13 No. 1, pp. 109-27.

Iwanow, H., McEachern, M.G. and Jeffrey, A. (2005), "The influence of ethical trading policies on consumer apparel purchase decisions: a focus on The Gap Inc", International Journal of Retail \& Distribution Management, Vol. 33 No. 5, pp. 371-87.

Jobber, D. (2006), Principles and Practice of Marketing, 5th ed., McGraw-Hill, Maidenhead.

Joergens, C. (2006), "Ethical fashion: myth or future trend?", Journal of Fashion Marketing and Management, Vol. 10 No. 3, pp. 360-71.

Jones, B., Temperley, J. and Lima, A. (2009), “Corporate reputation in the era of Web 2.0: the case of Primark”, Journal of Marketing Management, Vol. 25 No. 9 and 10, pp. 927-39.

Jones, P. and Comfort, D. (2005), "Corporate social responsibility and the UK's top ten retailers", International Journal of Retail \& Distribution Management, Vol. 39 No. 4, pp. 256-71.

Jones, P., Comfort, D. and Hillier, D. (2010), "Sustainability in the global shop window", International Journal of Retail \& Distribution Management, Vol. 33 No. 12, pp. 882-92. 
Jørgensen, A., Le Bocq, A., Nazarkina, L. and Hauschild, M. (2008), "Methodologies for social life cycle assessment", International Journal of Life Cycle Assessment, Vol. 13 No. 2, pp. 96-103.

Joung, H.M. and Park-Poaps, H. (2012), "Factors motivating and influencing clothing disposal behaviours", International Journal of Consumer Studies, available at: DOI: 10.1111/j.1470-6431.2011.01048.x. (accessed 25 March 12).

Keep and Share (2012), "Keep and Share philosophy", available at: www.keepandshare.co.uk/ index.html (accessed 25 March 2012).

Key Note (2006), “Clothing retailing marketing report”, Key Note, London, available at: www. keynote.co.uk (accessed 30 May 2011).

Key Note (2009), “Clothing retailing marketing report”, Key Note, London, available at: www. keynote.co.uk (accessed 30 May 2011).

Kilgallen, K. (2007), "Sainsbury's to go 100 per cent Fair Trade on TU T-shirts", Retail Week, 11 October, available at: www.retail-week.com/sainsburys-to-go-100-fair-trade-on-tu-tshirts/149419.article (accessed 27 May 2011).

Kim, S., Littrell, M. and Paff Ogle, J.L. (1999), "Social responsibility as a predictor of purchase intentions for clothing", Journal of Fashion Marketing and Management, Vol. 3 No. 3, pp. 207-18.

Klein, N. (2000), No Logo, Flamingo, London.

Kooistra, K. and Termorshuizen, J. (2006), The Sustainability of Cotton: Consequences for Man and the Environment, Science Shop, Wageningen UR.

Labour Behind the Label (2012), "Working conditions", available at: www.labourbehindthelabel. org/issues/itemlist/category/169-working-conditions (accessed 1 May 2012).

Laitala, K., Boks, C. and Klepp, I.G. (2011), "Potential for environmental improvements in laundering", International Journal of Consumer Studies, Vol. 35, pp. 254-64.

Levi Strauss (2012), "Product suppliers", available at: www.levistrauss.com/sustainability/ product/product-suppliers (accessed 24 April 2012).

Littrell, M. and Dickson, M.A. (1998), "Fair Trade performance in a competitive market”, Clothing and Textiles Research Journal, Vol. 16 No. 4, pp. 176-89.

Littrell, M.A., Ma, Y.J., Halepete, J. and Generation, X. (2005), "Baby Boomers, and swing: marketing Fair Trade apparel", Journal of Fashion Marketing and Management, Vol. 9 No. 4, pp. 407-19.

Low, W. and Davenport, E. (2006), "Mainstreaming Fair Trade: adoption, assimilation, appropriation", Journal of Strategic Marketing, Vol. 14 No. 4, pp. 315-27.

Made-By (2012), “Made-by mission”, available at: www.made-by.nl/madeby_missie.php?lg=en (accessed 20 April 2012).

Marks \& Spencer (2012), "Plan A", available at: http://plana.marksandspencer. com/ (accessed 12 May 2012).

Markkula, A. and Moisander, J. (2012), "Discursive confusion over sustainable consumption: a discursive perspective on the perplexity of marketplace knowledge", Journal of Consumer Policy, Vol. 35 No. 1, pp. 105-25.

Mintel (2007), Clothing Retailing - UK, Mintel, London.

Mintel (2008), Ethical and Green Retailing - UK, Mintel, London.

Mintel (2009), Clothing Retailing - UK, Mintel, London.

Moon, J., Anastasiasis, S. and Vigano, F. (2009), "The potential of CSR to support the implementation of the EU sustainability strategy: editorial introduction", Business Ethics: A European Review., Vol. 18 No. 3, pp. 268-72. 
IJRDM

40,12

954
NCC (2012), "Monthly prices", National Cotton Council of America, available at: www.cotton.org/ econ/prices/monthly.cfm (accessed 12 May 2012).

Nichols, A.J. (2002), "Strategic options in Fair Trade retailing", International Journal of Retail \& Distribution Management, Vol. 30 No. 1, pp. 6-17.

Oxfam (2012), "M\&S clothes exchange", available at: www.oxfam.org.uk/donate/donate-goods/ mands-clothes-exchange (accessed 12 May 2012).

Park, H. and Lennon, S.J. (2006), "The organizational factors influencing socially responsible apparel buying/sourcing", Clothing and Textiles Research Journal, Vol. 24 No. 3, pp. 229-47.

Park, H. and Stoel, L. (2005), "A model of socially responsible buying/sourcing decision-making processes”, International Journal of Retail \& Distribution Management, Vol. 33 No. 24, pp. 235-48.

People Tree (2012), "Producers", available at: www.peopletree.co.uk/ producers.php (accessed 12 May 2012).

Pretious, M. and Love, M. (2006), "Sourcing ethics and the global market: the case of the UK retail clothing sector", International Journal of Retail \& Distribution Management, Vol. 34 No. 2, pp. 892-903.

Rudell, F. (2006), "Shopping with a social conscience: consumer attitudes toward sweatshop labor", Clothing and Textiles Research Journal, Vol. 24, pp. 282-96.

Rushton, K. (2010), "Customers must bear brunt of cotton crunch, says Next”, Drapers, 5 November, available at: www.drapersonline.com/multiples/news/customers-must-bearbrunt-of-cotton-crunch-says-next/5018977.article (accessed 22 June 2011).

Shaw, D., Hogg, G., Wilson, E., Shui, E. and Hassan, L. (2006), "Fashion victim: the impact of Fair Trade concerns on clothing choice", Journal of Strategic Marketing, Vol. 14, pp. 427-40.

Shepard, A. (2008), "We sold our eco-dream to Timberland", The Times, 11 April, available at: http://women.timesonline.co.uk/tol/life_and_style/women/celebrity/article3727422.ece (accessed 22 June 2011).

Slater, K. (2003), Environmental Impact of Textiles: Production, Processes and Protection, Woodhead Publishing, Cambridge.

Strong, C. (1997), "The problems of translating Fair Trade principles into consumer purchase behaviour", Marketing Intelligence \& Planning, Vol. 15 No. 1, pp. 32-7.

(The) Textile Society (2010) Vol. 23, "Textile Society AGM and conference", available at: www. textilesociety.org.uk/events/event-details.php?textile-event=213 (accessed 23 November 2010).

Traid (2012), "Host a recycling bank", available at: www.traid.org.uk/host.html (accessed 24 March 2012).

Vulser, N. (2010), "Organic cotton struggles in French fashion industry", The Guardian, 23 November, available online at: www.guardian.co.uk/world/2010/nov/23/organic-cottonfrench-fashion-vulser (accessed 10 May 2011).

Webley, S. and Werner, A. (2008), "Corporate codes of ethics: necessary but not sufficient", Business Ethics: A European Review, Vol. 17 No. 4, pp. 405-15.

Wong, E. and Taylor, G. (2000), "An investigation of ethical sourcing practices: Levi Strauss \& Co", Journal of Fashion Marketing and Management, Vol. 4 No. 1, pp. 71-9.

Worn Again (2011), "Worn Again vision”, available at: www.wornagain.co.uk/pages/our-vision (accessed 10 May 2011).

Wright, L.T. and Heaton, S. (2006), "Fair Trade marketing: an exploration through qualitative research”, Journal of Strategic Marketing, Vol. 14 No. 4, pp. 411-26. 
Wrigley, P. (2008), "Ethics must stay high on the agenda", Drapers, 27 November, available at: www.drapersonline.com/news/ethics-must-stay-high-on-the-agenda/1936268.article (accessed 21 May 2011).
The sustainable clothing market

\begin{abstract}
About the authors
Helen Goworek is Senior Lecturer in Marketing in Nottingham Business School, Nottingham Trent University, and an Associate Tutor for postgraduate marketing courses in the School of Management at the University of Leicester. She previously worked in design and buying management roles in retail and manufacturing in the clothing industry. She has a first degree in Fashion and Marketing and an MA in Art and Design Education. Helen Goworek is the corresponding author and can be contacted at: helen.goworek@ntu.ac.uk

Tom Fisher is Professor of Art and Design in the School of Art and Design at Nottingham Trent University and previously worked at Sheffield Hallam University. Tom's background is in Fine Art, Design and Sociology. Having worked as a designer and maker of furniture and led an $\mathrm{MA}$ in Art and Design he wrote his $\mathrm{PhD}$ on the role of plastic materials in consumption experiences, in the sociology department at the University of York.

Tim Cooper is Professor of Sustainable Design and Consumption in the College of Art and Design and the Built Environment at Nottingham Trent University, having formerly worked at Sheffield Hallam University. He is responsible for leading research in the fields of sustainable design and sustainable consumption. He is a member of the University's Sustainability (Beyond Greening the Curriculum) Group and of the College Research Committee and Professoriate.

Dr Sophie Woodward is Lecturer in Sociology at the University of Manchester and previously worked in the School of Art and Design at Nottingham Trent University. She has carried out ethnographic research into women's wardrobes and has a continued interest in clothing as a form of material culture as this is involved in the construction of selfhood, and relationships to others. She collaborates with Professor Daniel Miller in the Global Denim Project, which is a network of academics working on diverse aspects of denim around the globe.

Alex Hiller is Head of MSc Programmes at Nottingham Business School, Nottingham Trent University. Alex's professional background is in quality management and marketing consultancy, and his teaching centres mainly around services marketing, customer service management and service quality management, alongside consumer behaviour and research methods. He has developed a strong research interest in ethical buying behaviour.
\end{abstract}

To purchase reprints of this article please e-mail: reprints@emeraldinsight.com Or visit our web site for further details: www.emeraldinsight.com/reprints 